(c) American Dairy Science Association, 2007.

\title{
Effects of Varying Doses of Supplemental Conjugated Linoleic Acid on Production and Energetic Variables During the Transition Period ${ }^{1}$
}

\author{
L. J. Odens, R. Burgos, M. Innocenti, M. J. VanBaale, and L. H. Baumgard ${ }^{2}$ \\ The Department of Animal Sciences, University of Arizona, Tucson 85721
}

\begin{abstract}
Supplementing a high dose of dietary conjugated linoleic acid (CLA) inhibits milk fat synthesis in dairy cows immediately postpartum. During negative net energy balance (EBAL), it appears that moderate CLA-induced milk fat depression causes a positive response in milk yield; however, as milk fat depression becomes more severe, the milk yield response diminishes. Multiparous Holstein cows ( $\mathrm{n}=31$ ) were randomly assigned to 1 of 3 treatments beginning $9 \pm 6 \mathrm{~d}$ before expected calving and ceased at $40 \mathrm{~d}$ in milk (DIM): 1) $578 \mathrm{~g} / \mathrm{d}$ of a rumen-inert (RI) palm fatty acid distillate (control), 2) $600 \mathrm{~g} / \mathrm{d}$ of RI-CLA for the entire trial period (CLA1), and 3) $600 \mathrm{~g} / \mathrm{d}$ of RI-CLA until 10 DIM followed by $200 \mathrm{~g} / \mathrm{d}$ for the remainder of the trial (CLA-2). Each dose provided equal amounts of fatty acids by replacing and balancing each treatment with a RI palm fatty acid distillate. Doses provided a total of $522 \mathrm{~g}$ of fatty acids/ $\mathrm{d}$ and 0,174 , or 58 (depending upon DIM) $\mathrm{g}$ of CLA (mixed isomers)/d. To improve palatability, doses were mixed with $600 \mathrm{~g} / \mathrm{d}$ of dried molasses; one-half of the supplement was fed at $0800 \mathrm{~h}$, and the remainder at 1900 h. Individual milk yield, dry matter intake, and body weight were recorded daily and milk composition determined every other day. There was no overall CLA effect on either the content or yield of milk protein or lactose. Both CLA treatments decreased overall milk fat content (26.0 and $18.3 \%$ ) and yield (22.5 and $17.3 \%)$ with CLA-induced milk fat depression becoming significant by $\mathrm{d} 8$. The CLA-induced milk fat depression increased in magnitude with progressing DIM until reaching a plateau on d 18 for CLA-1 (43\%) and on d 14 for CLA-2 (33\%), although neither milk fat trans-10, cis-12 CLA content $(1.8 \mathrm{mg} / \mathrm{g}$ ) nor its transfer efficiency (6.3\%) changed over time. Treatments had no effect on overall dry matter intake or milk yield, but there was a treatment $\times$ time interaction for milk production, as
\end{abstract}

\footnotetext{
Received May 19, 2006

Accepted August 23, 2006.

${ }^{1}$ This work was partially supported by the University of Arizona Experiment Station \#ARST-136339-H-24-130 and the United Dairymen of Arizona.

${ }^{2}$ Corresponding author: baumgard@ag.arizona.edu
}

cows fed either CLA treatment had increased milk yield after the second week of lactation. Cows fed either CLA treatment had a significant improvement in overall EBAL ( -5.1 vs. $-1.8 \mathrm{Mcal} / \mathrm{d})$, a decrease in nonesterified fatty acid levels (12\%), and an increase in glucose levels (11\%). A dietary supplement containing trans-10, cis12 CLA markedly improves EBAL and bioenergetic variables and increases milk yield in the total mixed ration-fed transitioning dairy cow.

Key words: conjugated linoleic acid, transition, milk fat, energy balance

\section{INTRODUCTION}

Cows in early lactation are typically unable to meet (i.e., consume) their energy requirements for both maintenance and copious milk production, and consequently are in a calculated net negative energy balance (NEBAL). The severity, magnitude, and timing of NEBAL nadir ( $\sim 4$ to 9 DIM) are associated with metabolic disorders and reproductive failures (Canfield and Butler, 1990; Drackley, 1999). The traditional (and frequently unsuccessful) approach to relieve or improve NEBAL during this time includes increasing dietary energy via concentrates or fats. Although this approach increases the ration energy density, these changes are often associated with negative affects such as rumen acidosis and reduced DMI (Hayirli and Grummer, 2004). A different approach is to decrease the milk energy content, thus manipulating the net energy balance (EBAL) equation on the energy expenditure side, rather than the energy intake portion. Milk fat is the most energetically expensive component to synthesize (50\% of total milk energy; Tyrrell and Reid, 1965) and the milk parameter most easily governed by management (Bauman and Davis, 1974). Therefore, regulating milk fat production via controlled milk fat depression (MFD) offers a novel technique to improve EBAL through the transition period.

Abomasal infusion of a conjugated linoleic acid (CLA) mixture and specifically the trans-10, cis-12 CLA isomer reduces milk fat synthesis and causes MFD (Chouinard et al., 1999; Baumgard et al., 2000, 2002a). Subsequent studies utilizing rumen inert (RI)-CLA demonstrated that MFD could be achieved during es- 
tablished lactation in both TMR (Giesy et al., 2002; Perfield et al., 2002; Moore et al., 2005a) and pasturebased systems (Mackle et al., 2003; Kay et al., 2006b). In contrast, the CLA dose effective during established lactation fails to alter milk fat synthesis immediately postpartum (i.e., within $3 \mathrm{wk}$; Bernal-Santos et al., 2003; Selberg et al., 2004; Castaneda-Gutierrez et al., 2005; Moore et al., 2005b). However, we have recently demonstrated that in both TMR (Moore et al., 2004) and pasture-based systems (Kay et al., 2006a), supplemental CLA can induce MFD immediately postpartum but a much larger $(\sim 3 \times)$ amount is required compared with that needed in established lactation. In both trials (Moore et al., 2004; Kay et al., 2006a), although MFD was apparent within a few days postcalving (2 to 4 DIM), the magnitude of MFD progressively increased as lactation advanced and maximum MFD was not obtained until approximately the second week of lactation. Kay et al. (2006a) also reported that moderate CLAinduced MFD appeared to cause a positive response in milk yield; however, as MFD became more severe ( $>35$ to $40 \%$ ), the increased milk yield response diminished.

Some abomasal CLA infusion trials (during established lactation) have demonstrated similar milk yield responses while utilizing a high CLA dose (Chouinard et al., 1999). Mackle et al. (2003) reported a quadratic milk yield response in pasture-fed cows and this response was correlated with the magnitude of CLA-induced MFD. This is further illustrated by a marked reduction $(40 \%)$ in milk synthesis as a result of abomasally infusing a large amount of a CLA mixture (Bell and Kennelly, 2003), a dose 4-fold higher (based upon the trans-10, cis-12 CLA content) necessary to evoke 40\% MFD (Baumgard et al., 2001; de Veth et al., 2004).

The study objective was to investigate if a high dietary RI-CLA dose (600 g/cow per d) fed pre- and postpartum (to immediately induce MFD) followed by a lower RI-CLA dose ( $200 \mathrm{~g} / \mathrm{cow}$ per d) at $10 \mathrm{~d}$ in milk (to prevent severe MFD) could increase and yet sustain a milk yield response. Additionally, we wanted to determine if reducing milk energy secretion via controlled MFD could improve EBAL and other bioenergetic parameters during the transition period.

\section{MATERIALS AND METHODS}

\section{Design, Animals, and Treatments}

The University of Arizona Institutional Animal Care and Use Committee approved all procedures involving animals. Multiparous Holstein cows $(\mathrm{n}=31)$ were randomly assigned to 1 of 3 treatments beginning $9 \pm 6 \mathrm{~d}$ before expected calving and ceased at 40 DIM: 1) 578 $\mathrm{g} / \mathrm{d}$ of a RI palm fatty acid distillate (control; EnergII, Bioproducts Inc., Fairlawn, OH), 2) 600 g/d of RI-CLA
Table 1. Fatty acid composition of lipid supplements ${ }^{1}$

\begin{tabular}{lcc}
\hline $\begin{array}{l}\text { Fatty acid, \% of total } \\
\text { fatty acids }\end{array}$ & Control & $\begin{array}{l}\text { Conjugated } \\
\text { linoleic } \\
\text { acid (CLA) }\end{array}$ \\
\hline C12:0 & 0.24 & 0.16 \\
C14:0 & 1.06 & 0.46 \\
C16:0 & 46.39 & 20.00 \\
C16:1 cis-9 & 0.16 & 0.14 \\
C18:0 & 4.43 & 2.87 \\
C18: 1 cis-9 & 36.79 & 32.58 \\
C18: 1 cis-11 & 0.64 & 0.73 \\
C18:2 cis-9, cis-12 & 9.23 & 3.37 \\
C18:2 trans-8, cis-10 CLA & $<0.01$ & 3.93 \\
C18:2 cis-9, trans-11 CLA & $<0.01$ & 4.08 \\
C18:2 trans-10, cis-12 CLA & $<0.01$ & 5.61 \\
C18:2 cis-11, trans-13 CLA & $<0.01$ & 5.56 \\
Other CLA isomers & $<0.01$ & 14.13 \\
C18:3 cis-9, cis-12, cis-15 & 0.44 & 0.15 \\
C20:0 & 0.34 & 0.25 \\
Unknown & 0.52 & 5.95 \\
Total CLA & $<0.01$ & 33.31 \\
\hline
\end{tabular}

${ }^{1}$ Cows were fed a dietary rumen-inert supplement containing $468 \mathrm{~g}$ of fatty acids/d from approximately $10 \mathrm{~d}$ precalving to $40 \mathrm{~d}$ postcalving.

(Bioproducts Inc.) for the entire trial period (CLA-1), or 3) $600 \mathrm{~g} / \mathrm{d}$ of RI-CLA until 10 DIM followed by 200 $\mathrm{g} / \mathrm{d}$ for the remainder of the trial (CLA-2). To maintain isoenergetic diets, each supplement provided an equal amount of total fatty acids by replacing and balancing treatments with RI palm fatty acid distillate (EnergGII, Bioproducts Inc.). Treatments provided a total of 522 $\mathrm{g}$ of fatty acids/d and 0,174 , or $58 \mathrm{~g}$ of CLA isomers/d (depending upon DIM). The CLA supplement contained a variety of isomers including $5.6 \%$ trans-10, cis-12 CLA (Table 1). To improve palatability, doses were mixed with $600 \mathrm{~g} / \mathrm{d}$ of dried molasses (Arizona Feeds, Tucson, AZ) and top-dressed twice daily, with one-half of the supplement provided at each of the 2 feedings. Cows were housed together in a single pen at the University of Arizona Dairy and were individually fed a TMR formulated to meet or exceed the predicted requirements (NRC, 2001) of energy, protein, minerals, and vitamins. Alfalfa hay was the main forage source, and steamflaked corn was the primary concentrate (Table 2). The TMR was sampled weekly, composited monthly, and analyzed by wet chemistry methods (Chandler Analytical Laboratories, Chandler, AZ). Cows were individually fed (using the Calan Broadbent feeding system; American Calan, Northwood, NH) ad libitum portions of fresh feed daily at 0800 and $1900 \mathrm{~h}$; orts were weighed and recorded daily at $0700 \mathrm{~h}$. Cows received a 300$\mathrm{mL}$ oral drench of propylene glycol on $\mathrm{d} 1,2$, and 3 postcalving. Shade and water were available at all times.

Cows were milked at 1000 and $2100 \mathrm{~h}$ and yield was recorded daily and condensed by week for statistical analysis. Milk samples were obtained from each cow 
Table 2. Dietary composition and chemical profile of pre-and postpartum diets

\begin{tabular}{|c|c|c|}
\hline Composition & Prepartum & Postpartum \\
\hline \multicolumn{3}{|l|}{ Ingredient, $\%$ of DM } \\
\hline Alfalfa hay & 54.0 & 49.5 \\
\hline Bermuda hay & 5.8 & - \\
\hline Whole cottonseed & 2.8 & 8.8 \\
\hline Amino Plus ${ }^{2}$ & - & 5.2 \\
\hline Molasses & 3.8 & 6.8 \\
\hline Citrus pulp & 5.4 & 5.1 \\
\hline Steam flaked corn & 21.3 & 19.9 \\
\hline Mineral and vitamin $\operatorname{mix}^{3,4}$ & 2.9 & 2.2 \\
\hline Supplement (EII or CLA) ${ }^{5}$ & 2.6 & 2.6 \\
\hline \multicolumn{3}{|l|}{ Chemical analysis, \% of DM } \\
\hline $\mathrm{CP}$ & 16.4 & 19.0 \\
\hline NDF & 28.6 & 37.5 \\
\hline $\mathrm{ADF}$ & 23.7 & 28.1 \\
\hline $\mathrm{NE}_{\mathrm{L}}, \mathrm{Mcal} / \mathrm{kg}$ of $\mathrm{DM}^{6}$ & 1.33 & 1.38 \\
\hline
\end{tabular}

${ }^{1}$ Values represent an average of samples collected and composited throughout the trial. Dry matter averaged 93\% and 50\% for the prepartum and postpartum diets, respectively.

${ }^{2}$ RUP; Ag Processing Corp., Omaha, NE.

${ }^{3}$ The prepartum supplement contained $2.22 \%$ fat, $7.0 \% \mathrm{Ca}, 3.0 \%$ $\mathrm{P}, 4.1 \% \mathrm{Mg}, 3.9 \% \mathrm{~S}, 0.3 \% \mathrm{~K}, 0.1 \% \mathrm{Na}, 24.6 \% \mathrm{Cl}, 1,788 \mathrm{mg} / \mathrm{kg}$ of $\mathrm{Zn}$, $1,515 \mathrm{mg} / \mathrm{kg}$ of $\mathrm{Mn}, 691 \mathrm{mg} / \mathrm{kg}$ of $\mathrm{Fe}, 443 \mathrm{mg} / \mathrm{kg}$ of $\mathrm{Cu}, 59 \mathrm{mg} / \mathrm{kg}$ of Co, $12 \mathrm{mg} / \mathrm{kg}$ Se, $5 \mathrm{mg} / \mathrm{kg}$ of Mo, $12 \mathrm{mg} / \mathrm{kg} \mathrm{I}, 549 \mathrm{IU} / \mathrm{g}$ of vitamin A, $67 \mathrm{IU} / \mathrm{g}$ of vitamin $\mathrm{D}$, and $7 \mathrm{IU} / \mathrm{g}$ of vitamin $\mathrm{E}$.

${ }^{4}$ The postpartum supplement contained $1.26 \%$ fat, $6.44 \% \mathrm{Ca}, 7.22 \%$ $\mathrm{P}, 4.41 \% \mathrm{Mg}, 0.56 \% \mathrm{~S}, 0.17 \% \mathrm{~K}, 15.93 \% \mathrm{Na}, 0.01 \% \mathrm{Cl}, 2,477.8 \mathrm{mg} /$ $\mathrm{kg}$ of Zn, 2,094.2 mg/kg of Mn, 1,214.4 mg/kg of Fe, $686.3 \mathrm{mg} / \mathrm{kg}$ of $\mathrm{Cu}, 82.1 \mathrm{mg} / \mathrm{kg}$ of Co, $15.1 \mathrm{mg} / \mathrm{kg}$ Se, $12.5 \mathrm{IU} / \mathrm{g}$ of vitamin D, and 0.9 IU/g of vitamin $\mathrm{E}$.

${ }^{5}$ Calcium salts of palm fatty acid distillate or calcium salts of a fatty acid mixture containing conjugated linoleic acid (CLA) isomers.

${ }^{6} \mathrm{NE}_{\mathrm{L}}$ values do not include additional energy provided by the treatment supplements.

on d $2,4,6,8,10,12,14,16,18,20,27,34$, and 40 . One aliquot from each sampling was stored at $4^{\circ} \mathrm{C}$ with a preservative (bronopol tablet), and component content was analyzed at the Arizona DHIA laboratory (Tempe, AZ) using national DHI standards and AOAC-approved (2000) mid infrared analysis equipment and procedures. A second aliquot, from d 2, 8, and 20 was stored at $-20^{\circ} \mathrm{C}$ until analyzed for fatty acid composition. Blood samples were obtained from each cow on d 1, 7, 14, 21, 28,35 , and $40 \pm 1$ DIM. Samples were kept on ice until centrifuged at $3,000 \times \mathrm{g}$ for $15 \mathrm{~min}$. Plasma was split into 2 aliquots, frozen at $-20^{\circ} \mathrm{C}$, and later analyzed for NEFA and glucose concentrations. Plasma NEFA and glucose levels were determined enzymatically using commercially available kits validated for use in our laboratory (NEFA C kit; Wako Chemicals USA, Richmond VA; lot \#23Q5; Autokit Glucose C2; Wako Chemicals USA, Inc., lot \#KJ091). These procedures were scaled down and conducted in 96-well microplates (Rainin Instrument, LLC, Oakland, CA) and read using a microplate photometer (Multiskan Ascent, Thermo Electron Corporation, Vantaa, Finland). The inter- and intraassay coefficients for the NEFA and glucose assay were 5.8 and $2.4 \%$ (NEFA), and 6.8 and $2.6 \%$ (glucose).

Starting at 1 DIM, BW from each animal were recorded daily, and condensed by week for statistical analysis. Animals were weighed following the morning milking. Body condition scores were estimated independently by 2 trained individuals on d 1, 7, 14, 21, 28, 35, and $40 \pm 1 \mathrm{~d}$ postcalving using a 5 -point system (Roche et al., 2004) and scores were averaged for statistical purposes. Daily observations and general health records were recorded throughout the study.

\section{Colostrum Sampling and Analysis}

Colostrum samples were obtained from all cows at the first milking after parturition and analyzed for IgG content. To prevent calves from nursing, the calf was removed from the dam immediately after parturition. Colostrum IgG values were determined by RIA (New Mexico State University, Las Cruces, NM) and assay procedures were as previously described (Duff et al., 2000). All samples were analyzed within the same assay and the intraassay coefficient of variation was $6.8 \%$.

\section{Fatty Acid Analysis}

Fatty acid methyl esters were prepared by the transmethylation procedure as described by Chouinard et al. (1999). Fatty acid methyl esters were quantified using a gas chromatograph (Hewlett Packard GC system 6890; Wilmington, DE) equipped with a flame-ionization detector and a CP-7489 fused silica capillary column (100 $\mathrm{m} \times 0.25 \mathrm{~mm}$ i.d. with $0.2 \mu \mathrm{m}$ film thickness; Varian, Walnut Creek, CA). Oven, inlet, and detector temperatures, ramping and gas flow rates along with fatty acid identification methods were as previously described (Moore et al., 2004, 2005a; Kay et al., 2006b).

\section{Calculations}

Prepartum energy balance was calculated using the following equation: Energy balance = net energy of intake - (net energy of maintenance + net energy of pregnancy). Net energy intake was calculated by multiplying the daily DMI by the calculated net energy value of the diet plus the net energy value of the supplement (calculated using 2001 NRC energy values for molasses and calcium soaps of fat). Energy requirement for maintenance was computed using the following equation (NRC, 2001): Net energy of maintenance $=0.08 \times$ $\mathrm{BW}^{0.75}$. Pregnancy requirements were estimated using the following equation (NRC, 2001): Net energy of pregnancy $=[(0.00318 \times$ days pregnant -0.0352$) \times($ calf BW/ 45)]/0.218. Calves were not weighed after parturition; 
Table 3. Effect of supplementing rumen inert-conjugated linoleic acid (RI-CLA) for $40 \mathrm{~d}$ postcalving on milk production parameters in TMR-fed cows ${ }^{1}$

\begin{tabular}{|c|c|c|c|c|c|c|c|}
\hline \multirow[b]{2}{*}{ Parameter } & \multicolumn{3}{|c|}{ Treatments $^{2}$} & \multirow[b]{2}{*}{ SEM } & \multicolumn{3}{|c|}{$P$} \\
\hline & Control & CLA-1 & CLA-2 & & TRT & $\mathrm{TRT} \times \mathrm{WOL}^{3}$ & Contrast $^{4}$ \\
\hline DMI, kg/d & 17.9 & 19.3 & 19.8 & 1.1 & 0.42 & 0.74 & 0.21 \\
\hline Net energy intake, Mcal/d & 28.0 & 29.7 & 30.7 & 1.2 & 0.33 & 0.91 & 0.17 \\
\hline Milk yield, $\mathrm{kg} / \mathrm{d}$ & 35.56 & 38.23 & 38.50 & 2.13 & 0.57 & 0.02 & 0.29 \\
\hline $3.5 \% \mathrm{FCM},{ }^{5} \mathrm{~kg} / \mathrm{d}$ & 37.99 & 32.66 & 35.15 & 2.03 & 0.21 & 0.28 & 0.11 \\
\hline \multicolumn{8}{|l|}{ Milk fat } \\
\hline$\%$ & $4.27^{\mathrm{a}}$ & $3.16^{\mathrm{b}}$ & $3.49^{\mathrm{b}}$ & 0.15 & $<0.01$ & 0.12 & $<0.01$ \\
\hline $\mathrm{g} / \mathrm{d}$ & $1,409^{\mathrm{a}}$ & $1,091^{b}$ & $1,165^{\mathrm{b}}$ & 66 & $<0.01$ & 0.69 & $<0.01$ \\
\hline \multicolumn{8}{|l|}{ Milk protein } \\
\hline$\%$ & 3.22 & 3.38 & 3.46 & 0.17 & 0.61 & 0.61 & 0.36 \\
\hline $\mathrm{g} / \mathrm{d}$ & 1,052 & 1,182 & 1,158 & 67 & 0.37 & 0.07 & 0.16 \\
\hline \multicolumn{8}{|l|}{ Milk lactose } \\
\hline$\%$ & 4.54 & 4.48 & 4.46 & 0.06 & 0.68 & 0.21 & 0.41 \\
\hline $\mathrm{g} / \mathrm{d}$ & 1,207 & 1,399 & 1,440 & 126 & 0.39 & 0.66 & 0.18 \\
\hline $\mathrm{SCC}, \times 1,000$ & 584 & 926 & 1,061 & 301 & 0.52 & 0.35 & 0.28 \\
\hline $\mathrm{IgG},{ }^{6} \mathrm{mg} / \mathrm{mL}$ & 15.0 & 17.9 & 22.7 & 2.8 & - & - & 0.15 \\
\hline
\end{tabular}

${ }^{\mathrm{a}, \mathrm{b}}$ Values within rows with differing superscripts differ at $P<0.05$.

${ }^{1}$ Average over the 40 -d postpartum period unless otherwise noted.

${ }^{2}$ Treatments were EnerGII (control); $600 \mathrm{~g} / \mathrm{cow}$ per d of RI-CLA (CLA-1); stepwise dose of $600 \mathrm{~g} / \mathrm{cow}$ per d of RI-CLA followed by $200 \mathrm{~g} /$ cow per d at 10 DIM (CLA-2).

${ }^{3} \mathrm{WOL}=$ Week of lactation.

${ }^{4}$ Control vs. CLA-1 and CLA-2.

${ }^{5} \mathrm{FCM}=(0.432 \times$ milk yield $)+(16.23 \times$ milk fat yield $)$.

${ }^{6} \mathrm{An}$ average of the first milking postparturition.

therefore, an average calf weight of $45 \mathrm{~kg}$ was used to equate net energy of pregnancy. Postpartum energy balance was estimated using the following equation $(\mathrm{NRC}, 2001)$ : Energy balance $=$ net energy of intake (net energy of maintenance + net energy of lactation). Net energy of propylene glycol was added for $\mathrm{d} 1,2$, and 3 postpartum. Net energy of lactation was estimated by the following equation: $[(0.0929 \times$ fat $\%)+(0.0547 \times \mathrm{CP}$ $\%)+(0.0395 \times$ lactose $\%)] \times$ milk production. Daily EBAL values were subjected to a third-order polynomial regression analysis to minimize variation, and predicted daily energy values from these equations were used in the statistical analysis as previously described (Lucy et al., 1991; Moore et al., 2004). Days to EBAL nadir were calculated as the day in milk at the time the nadir occurred. Fat-corrected milk was calculated (NRC, 2001) using the following equations: $3.5 \% \mathrm{FCM}=$ $(0.432 \times$ milk yield $)+(16.23 \times$ milk fat yield $)$.

The $\Delta^{9}$-desaturase index was calculated using the equation: $\Delta^{9}$-desaturase index $=100 \times[(14: 1+16: 1+$ $18: 1$ cis- $9+18: 2$ cis- 9 , trans -11$) /(14: 1+16: 1+18: 1$ cis$9+14: 0+16: 0+18: 0+18: 1$ trans -11$)]$.

\section{Statistical Analysis}

Milk yield, DMI, milk components, milk fatty acid profiles, plasma NEFA and glucose, EBAL, change in $\mathrm{BW}$, and change in BCS were analyzed by repeated measures using the PROC MIXED procedure of SAS
(SAS Institute, 2005) with an autoregressive covariance structure and week of lactation or day of lactation as the repeated affect. All data were covariately adjusted using the previous lactation mature equivalent milk yield. The model contained week of lactation, treatment, and week/day of lactation $\times$ treatment interactions. Cows were the random effect, and week/day of lactation, treatment, and week/day of lactation $\times$ treatment interaction were the fixed effects. Energy balance nadir, NEFA peak, and IgG concentration were analyzed using the PROC MIXED procedure of SAS (SAS Institute, 2005) with treatment as the dependent variable, and did not contain a time or repeated component. Preplanned statistical comparisons were conducted for control vs. both CLA treatments (CLA-1 and CLA-2) using the CONTRAST statement of SAS. As expected with a transition cow trial, most measured parameters markedly changed with advancing lactation and therefore the level of significance for the time effect was not reported for these variables. Parameters of interest having a significant treatment by time interaction are temporally presented in figures. Standard errors of the mean are reported and differences considered significant when $P<0.05$ unless otherwise stated.

\section{RESULTS}

Overall milk fat content and yield was decreased by CLA supplementation (Table 3) with CLA-induced MFD becoming significant for both CLA treatments by 

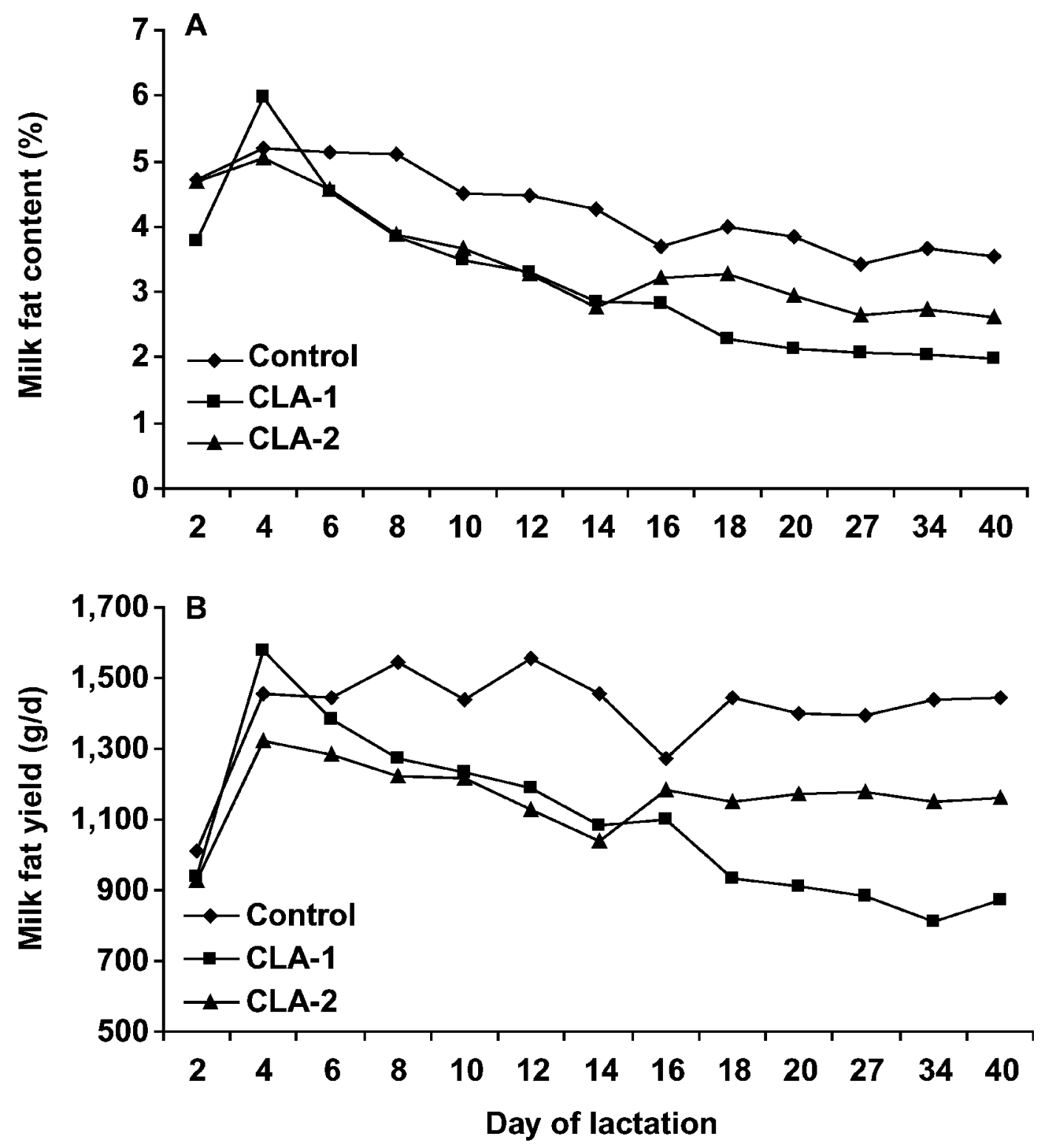

Figure 1. Temporal pattern of milk fat content (A) and yield (B) from cows fed rumen inert-conjugated linoleic acid (RI-CLA) during early lactation. Treatments were EnerGII (control); $600 \mathrm{~g} / \mathrm{cow}$ per d of RI-CLA (CLA-1); stepwise dose of $600 \mathrm{~g} / \mathrm{cow}$ per d of RI-CLA followed by $200 \mathrm{~g} / \mathrm{cow}$ per d at 10 DIM (CLA-2). Values represent least squares means ( $\mathrm{n}=9$ or 11, respectively) for the control and RI-CLA doses; SEM for milk fat content averaged 0.35 and ranged from 0.34 to $0.37 \%$; SEM for milk fat yield averaged 129 and ranged from 123 to 147 $\mathrm{g} / \mathrm{d}$.

d 8 (24\%; Figure 1). The magnitude of CLA-induced MFD continued for CLA-1 during the first $\sim 18 \mathrm{~d}$ postpartum at which point it reached a plateau $(\sim 43 \%$; Figure 1). Conjugated linoleic acid-induced MFD for CLA2 reached a nadir at $\sim 14 \mathrm{~d}$ postpartum $(\sim 33 \%)$ but plateaued at $24 \%$ from approximately 18 DIM until study completion (Figure 1).

There was no overall treatment or treatment by time interactions effect on either the content or yield of milk protein or lactose, SCC, or IgG content (Table 3). Al- though there was no overall treatment effect on milk yield, there was a treatment $\times$ week of lactation interaction $(P<0.05$; Table 3$)$ because cows fed CLA had increased milk yield after the second week of lactation (Figure 2).

Overall DMI and energy intake were not affected by treatment $(P>0.27$; Table 3$)$, and there was no treatment $\times$ time interaction. Cows fed the CLA treatments lost less body condition $(P<0.05$; Table 4$)$ than controls. Calculated EBAL was improved ( 3 Mcal/d, $P<0.05$; 


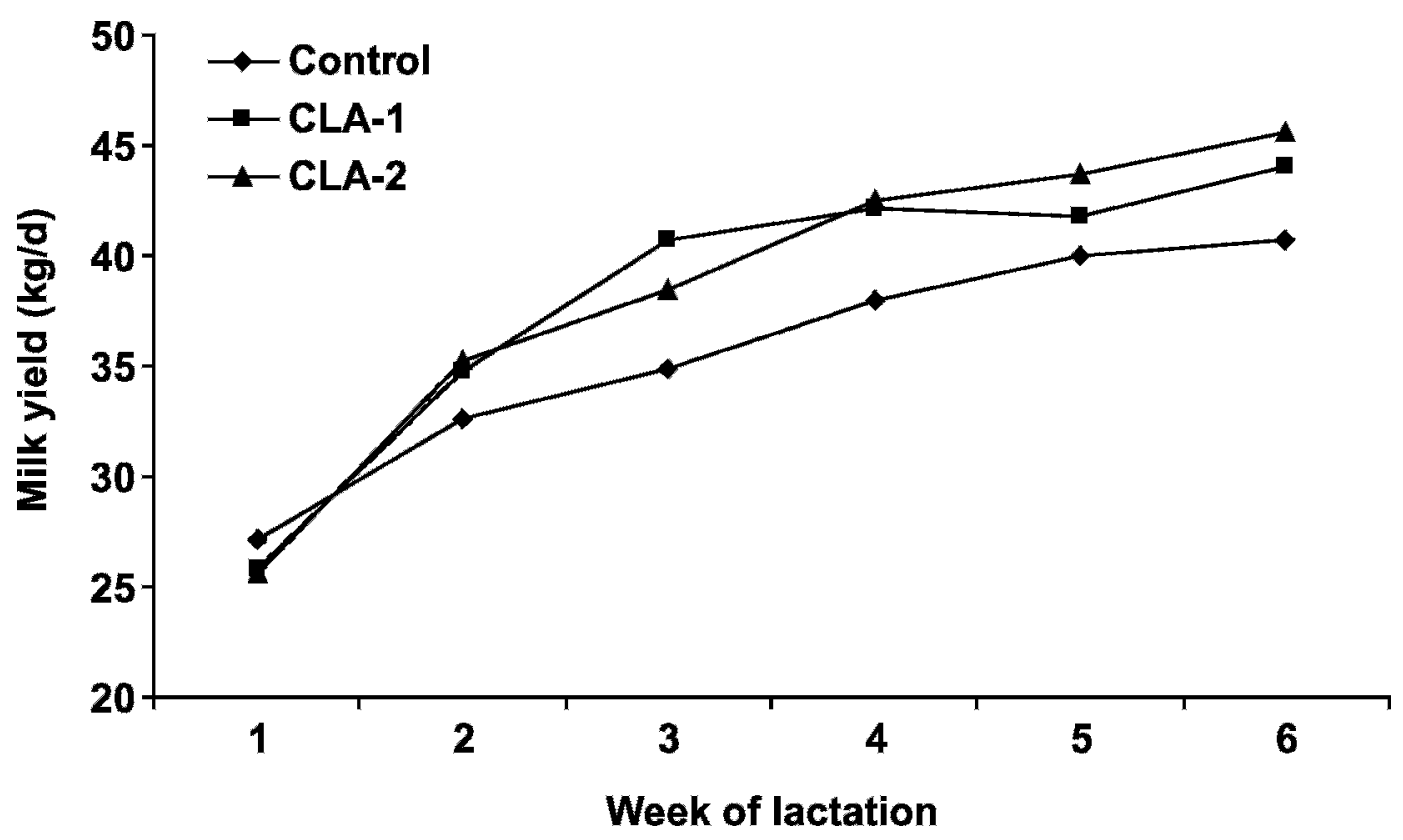

Figure 2. Effects of supplementing rumen-inert conjugated linoleic acid (RI-CLA) for $10 \mathrm{~d}$ precalving to $40 \mathrm{~d}$ postcalving on the temporal pattern of milk yield during the first $40 \mathrm{~d}$ postpartum. Treatments were EnerGII (control); $600 \mathrm{~g} / \mathrm{cow}$ per d of RI-CLA (CLA-1); stepwise dose of $600 \mathrm{~g} / \mathrm{cow}$ per d of RI-CLA followed by $200 \mathrm{~g} / \mathrm{cow}$ per d at 10 DIM (CLA-2). Values represent least squares means (n = 9 or 11 , respectively) for the control and RI-CLA doses; SEM for milk yield averaged 2.3 and ranged from 2.3 to $2.4 \mathrm{~kg} / \mathrm{d}$.

Table 4 and Figure 3) by CLA feeding compared with controls but NEBAL nadir $(-7.0 \mathrm{Mcal})$ and days to NEBAL nadir (8.4) were not affected by treatment (Table 4). Overall plasma NEFA levels were decreased (488 vs. $607 \mu \mathrm{Eq} / \mathrm{L}, P<0.05$; Table 3 ) in the CLA treatments compared with controls (Figure 4A) and both CLA treatments increased $(65.3 \mathrm{vs} .58 .7 \mathrm{mg} / \mathrm{dL} ; P<0.01)$ circulating plasma glucose (Figure 4B; Table 4)

Both CLA supplements decreased the yield of de novo synthesized milk fatty acids, reduced the production of

Table 4. Effects of supplementing rumen inert-conjugated linoleic acid (RI-CLA) for $40 \mathrm{~d}$ postcalving on energetic variables in TMR-fed cows ${ }^{1}$

\begin{tabular}{|c|c|c|c|c|c|c|c|}
\hline \multirow[b]{2}{*}{ Variable } & \multicolumn{3}{|c|}{ Treatments $^{2}$} & \multirow[b]{2}{*}{ SEM } & \multicolumn{3}{|c|}{$P$} \\
\hline & Control & CLA-1 & CLA-2 & & TRT & TRT $\times$ Time & Contrast $^{3}$ \\
\hline BW, kg & 621.6 & 676.4 & 662.5 & 20.1 & 0.16 & 0.05 & 0.06 \\
\hline BW loss, ${ }^{4,5} \mathrm{~kg}$ & $51.7^{\mathrm{a}}$ & $50.8^{\mathrm{a}}$ & $23.0^{\mathrm{b}}$ & 6.9 & $<0.01$ & 0.05 & 0.10 \\
\hline BCS & 3.00 & 2.90 & 2.90 & 0.12 & 0.72 & 0.31 & 0.42 \\
\hline BCS $\operatorname{loss}^{5,6}$ & $0.53^{\mathrm{a}}$ & $0.27^{\mathrm{ab}}$ & $0.19^{b}$ & 0.12 & 0.10 & 0.36 & 0.04 \\
\hline $\mathrm{EBAL},{ }^{7} \mathrm{Mcal} / \mathrm{d}$ & -5.11 & -1.29 & -2.24 & 1.28 & 0.12 & 0.05 & 0.04 \\
\hline EBAL nadir ${ }^{5,8} \mathrm{~d}$ & 8.8 & 6.6 & 9.8 & 1.5 & 0.32 & - & 0.72 \\
\hline EBAL nadir, ${ }^{5,8} \mathrm{Mcal}$ & -8.3 & -6.9 & -5.7 & 1.6 & 0.52 & - & 0.31 \\
\hline NEFA ${ }^{8} \mu \mathrm{Eg} / \mathrm{L}$ & $607^{\mathrm{a}}$ & $502^{\mathrm{ab}}$ & $474^{\mathrm{b}}$ & 43 & 0.08 & 0.49 & 0.03 \\
\hline Glucose, $\mathrm{mg} / \mathrm{dL}$ & $58.7^{\mathrm{a}}$ & $65.6^{\mathrm{b}}$ & $64.9^{\mathrm{b}}$ & 1.5 & $<0.01$ & 0.81 & $<0.01$ \\
\hline
\end{tabular}

${ }^{\mathrm{a}, \mathrm{b}}$ Values within rows with differing superscripts differ at $P<0.05$.

${ }^{1}$ Average over the 40 -d postpartum period unless otherwise noted.

${ }^{2}$ Treatments were EnerGII (control); $600 \mathrm{~g} / \mathrm{cow}$ per d of RI-CLA (CLA-1); stepwise dose of $600 \mathrm{~g} / \mathrm{cow}$ per d of RI-CLA followed by $200 \mathrm{~g} /$ cow per d at 10 DIM (CLA-2).

${ }^{3}$ Control vs. CLA-1 and CLA-2.

${ }^{4}$ Calculated as the weekly BW change from the average of the first $3 \mathrm{~d}$ postpartum.

${ }^{5}$ Not averaged over the $40 \mathrm{~d}$ postpartum period but represent one point in time or a delta in time.

${ }^{6}$ Calculated as the weekly BCS change from $\mathrm{d} 1$ postpartum.

${ }^{7}$ Mean net energy balance $(\mathrm{EBAL})=$ net energy intake $-($ net energy for maintenance + net energy for lactation).

${ }^{8}$ Calculated using a third-order polynomial regression. 


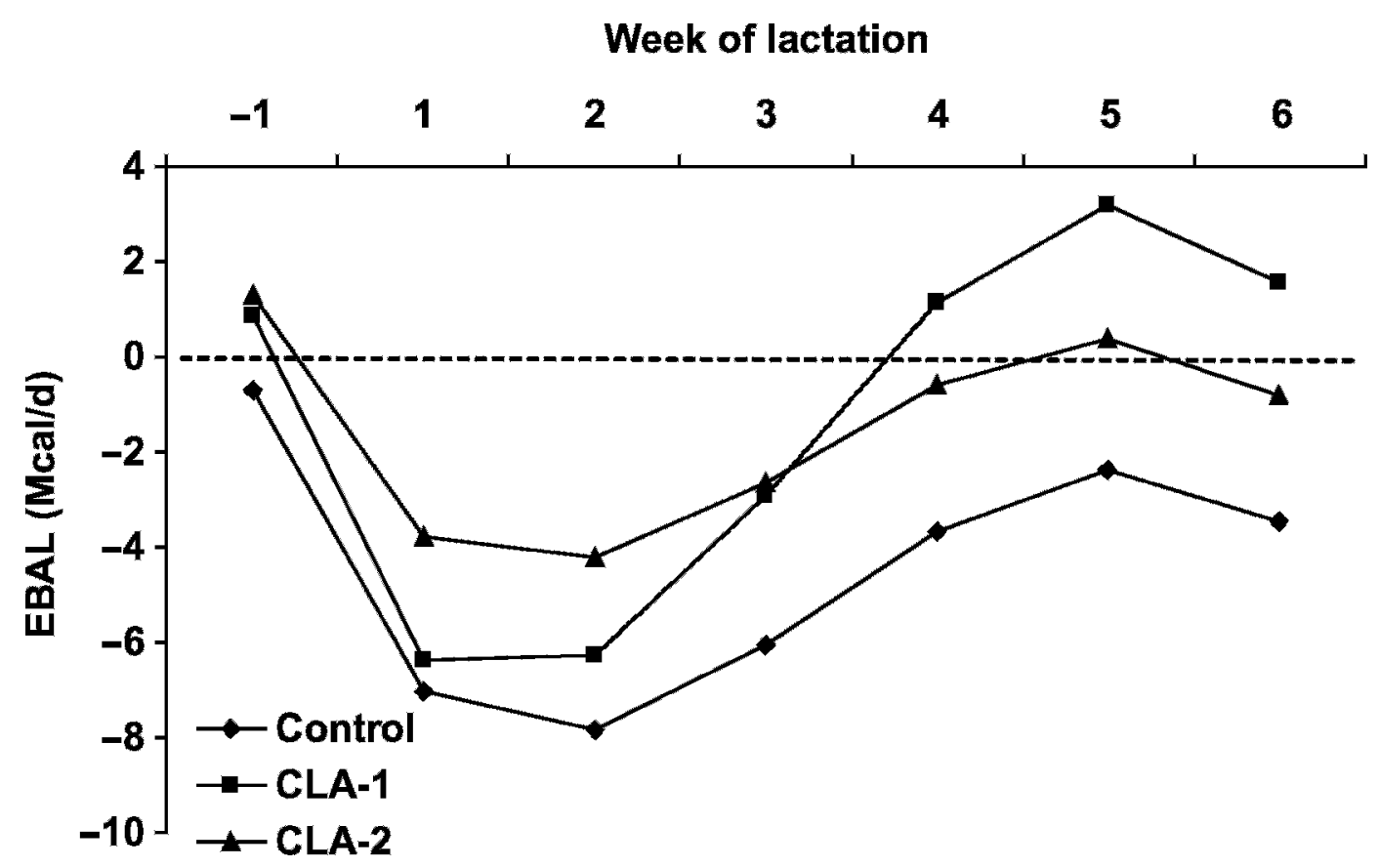

Figure 3. Effects of supplementing rumen-inert conjugated linoleic acid (RI-CLA) for $10 \mathrm{~d}$ precalving to $40 \mathrm{~d}$ postcalving on the temporal pattern of energy balance (EBAL) during the $10 \mathrm{~d}$ precalving to $40 \mathrm{~d}$ postcalving. Treatments were EnerGII (control); $600 \mathrm{~g} / \mathrm{cow}$ per $\mathrm{d}$ of RI-CLA (CLA-1); stepwise dose of $600 \mathrm{~g} / \mathrm{cow}$ per d of RI-CLA followed by $200 \mathrm{~g} / \mathrm{cow}$ per d at 10 DIM (CLA-2). Values represent least squares means ( $\mathrm{n}=9$ or 11, respectively) for the control and RI-CLA doses; SEM for weekly EBAL averaged 1.45 and ranged from 1.41 to 1.52 $\mathrm{Mcal} / \mathrm{d}$.

16:0 and 16:1 (fatty acids originating from both de novo and preformed sources), but did not alter the yield of preformed fatty acids (>17:0; Table 5 ). There was a time by treatment interaction for de novo fatty acid content (Table 5), because neither CLA treatment altered these fatty acids at 2 or 8 DIM, but did reduce them (155 vs. $118 \mathrm{mg} / \mathrm{g}$ ) by $20 \mathrm{DIM}$ (data not shown). Both CLA treatments overall decreased the content of 16:0 and 16:1 and increased the content of long-chain fatty acids (>17:0; Table 5). There were few or no overall effects $(\mathrm{P}>0.05)$ on the fatty acid ratios representing the $\Delta^{9}$ desaturase system nor on the overall $\Delta^{9}$-desaturase index (Table 5). Milk fat trans-10, cis-12 CLA was undetectable in controls, averaged $2.0 \mathrm{mg} / \mathrm{g}$ in the CLA-1 treatment and was temporally independent, and averaged $1.6 \mathrm{mg} / \mathrm{g}$ in the CLA-2 treatment and was temporally dependent, because it expectedly decreased in content after 10 DIM.

\section{DISCUSSION}

Energy intake during the periparturient period is often insufficient to meet maintenance and milk synthesis requirements and cows typically enter into NEBAL (Drackley, 1999). In addition, the transition from gestation to lactation requires a substantial metabolic shift that must be effectively accomplished for a successful lactation (Bauman and Currie, 1980; Drackley, 1999). Prolonged days to first ovulation, acyclicity, and subsequent reproductive failure, metabolic problems, and decreased production are associated with duration, magnitude, and days to NEBAL nadir and can be exacerbated by transition period disorders (Canfield and Butler, 1990; Butler, 2001; Baumgard et al., 2006). To capture the large pre- and postparturient metabolic changes, we initiated treatments approximately $10 \mathrm{~d}$ before anticipated calving and continued dietary treatments until cows approached zero EBAL (40 DIM).

A dietary supplement of CLA during established lactation decreases milk fat from cows either consuming a TMR (Chouinard et al., 1999; Giesy et al., 2002; Perfield et al., 2002; Moore et al., 2005a,b) or when rotationally grazed (Mackle et al., 2003; Kay et al., 2006b). Early supplemental CLA studies conducted with transition cows fed a similar amount of CLA as utilized in established lactation (Bernal-Santos et al., 2003; Selberg et al., 2004; Castaneda-Gutierrez et al., 2005) indicate that CLA did not induce MFD until the third or fourth week of lactation ( 2 or 3 wk post-NEBAL nadir). We have hypothesized that, in order for CLA-induced MFD to be used as an EBAL management tool during the transition period, it must be effective immediately 

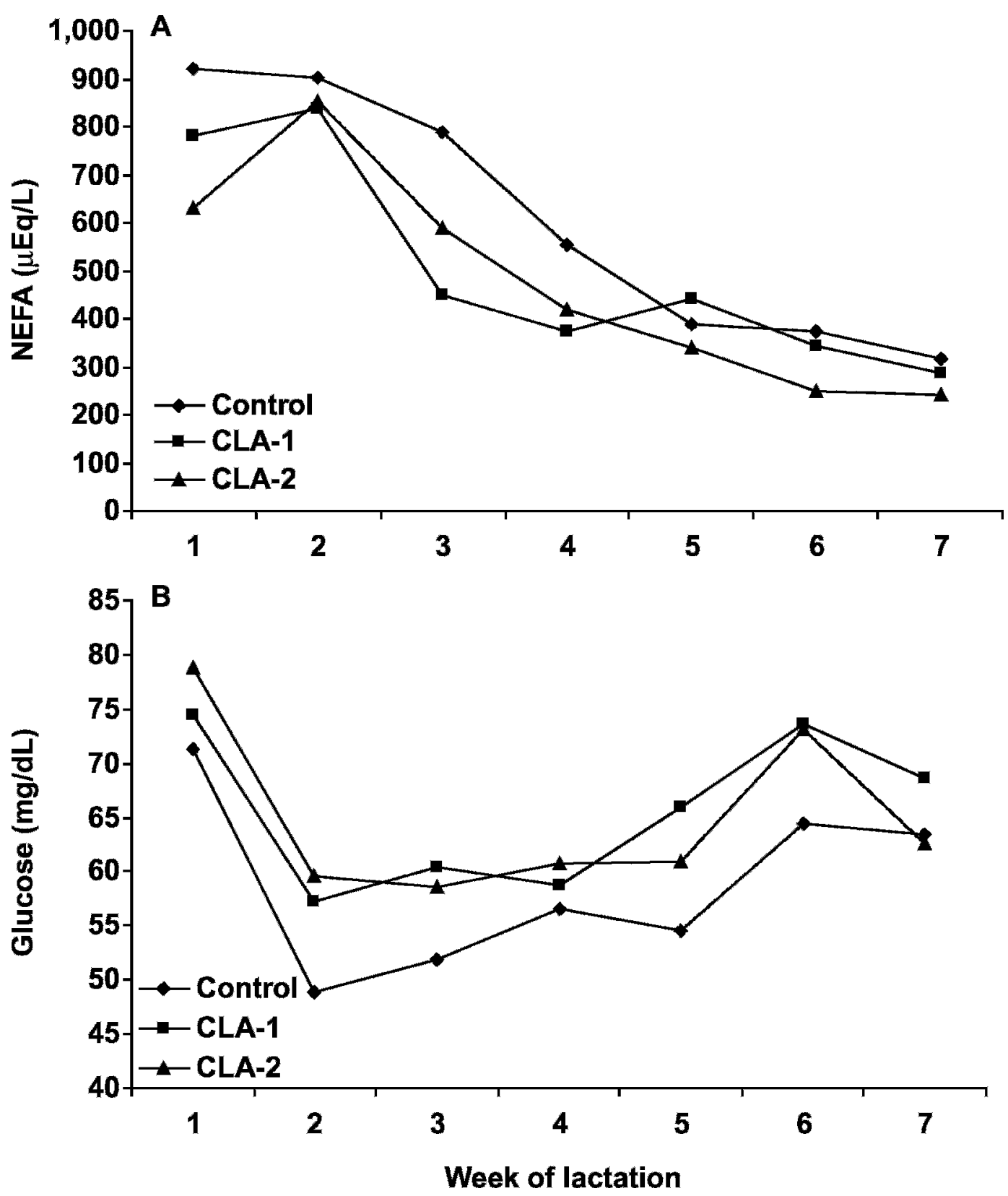

Figure 4. Effects of supplementing rumen-inert conjugated linoleic acid (RI-CLA) for $10 \mathrm{~d}$ precalving to $40 \mathrm{~d}$ postcalving on the temporal pattern of NEFA concentration (A) and glucose concentration (B) during the first $40 \mathrm{~d}$ postpartum. Treatments were EnerGII (control); 600 g/cow per d of RI-CLA (CLA-1); stepwise dose of $600 \mathrm{~g} / \mathrm{cow}$ per d of RI-CLA followed by $200 \mathrm{~g} / \mathrm{cow}$ per d at 10 DIM (CLA-2). Values represent least squares means ( $\mathrm{n}=9$ or 11, respectively) for the control and RI-CLA doses; SEM for weekly NEFA averaged 84.1 and ranged from 81.3 to $93.3 \mu \mathrm{Eq} / \mathrm{L}$ per d; SEM for weekly glucose averaged 3.4 and ranged from 3.3 to $3.6 \mathrm{mg} / \mathrm{dL}$ per $\mathrm{d}$.

postpartum (Bauman et al., 2001; Baumgard et al., $2002 \mathrm{~b}, 2006)$. We illustrated that by tripling the amount of CLA fed to transition cows (compared with that fed during late lactation), MFD could be achieved within days after parturition (Moore et al., 2004; Kay et al., 2006a) and the current trial confirms this (Figure 1) because milk fat content was statistically reduced by 8 DIM. As expected, the MFD magnitude increased as lactation progressed and maximized around d 18 for CLA-1 $(43 \%)$ and d 14 for CLA-2 (33\%). Despite the increase in milk production compared with controls, overall milk fat yield was reduced for CLA-1 and CLA2 by 38 and $18 \%$, respectively.

There was a treatment by week of lactation interaction on milk yield because CLA-fed cows had similar production in early lactation ( $\leq 2 \mathrm{wk}$ ) but enhanced yield 
Table 5. Effect of supplementing rumen inert-conjugated linoleic acid (RI-CLA) for $40 \mathrm{~d}$ postcalving on milk fatty acid origin and desaturase variables in TMR-fed dairy cows ${ }^{1}$

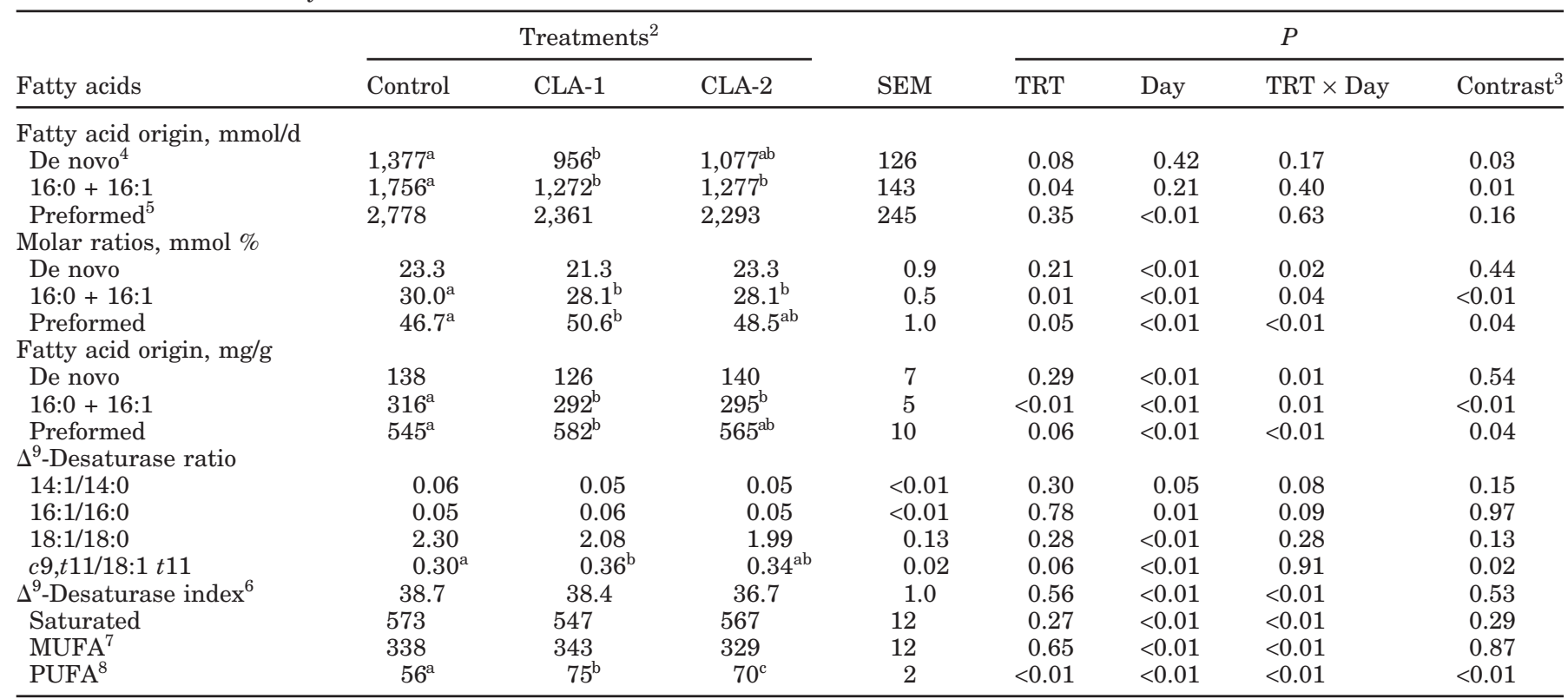

${ }^{\mathrm{a}-c}$ Values within rows with differing superscripts differ at $P<0.05$.

${ }^{1}$ Average of $\mathrm{d} 2,8$, and 20 postpartum.

${ }^{2}$ Treatments were EnerGII (control); $600 \mathrm{~g} / \mathrm{cow}$ per d of RI-CLA (CLA-1); stepwise dose of $600 \mathrm{~g} / \mathrm{cow}$ per d of RI-CLA followed by $200 \mathrm{~g} /$ cow per d at 10 DIM (CLA-2).

${ }^{3}$ Control vs. CLA-1 and CLA-2.

${ }^{4}$ Sum of $4: 0$ to $15: 0$.

${ }^{5}$ Sum of 17:0 to 20:0.

${ }^{6} \Delta^{9}$-desaturase index calculated by $100 \times\left[\left(\mathrm{C}_{14: 1}+\mathrm{C}_{16: 1}+\mathrm{C}_{18: 1} c_{9}+\mathrm{C}_{18: 2} c 9, t 11\right) /\left(\mathrm{C}_{14: 1}+\mathrm{C}_{16: 1}+\mathrm{C}_{18: 1} c_{9}+\mathrm{C}_{14: 0}+\mathrm{C}_{16: 0}+\mathrm{C}_{18: 0}+\mathrm{C}_{18: 1 t 11}\right)\right]$.

${ }^{7}$ Monounsaturated fatty acids.

${ }^{8}$ Polyunsaturated fatty acids.

as lactation progressed ( $\geq \mathrm{wk} 3$; Figure 2 ). We had anticipated that the CLA-1-induced milk yield response would diminish as lactation advanced and MFD became more severe, and that the reduction in the CLA dose at 10 DIM would cause a sustained milk yield response. The association between moderate MFD and an increase in milk or milk component synthesis would presumably only hold true when the animal is either in NEBAL or in a period of nutrient insufficiency (Baumgard et al., 2006). This probably explains why CLAinduced moderate MFD (i.e., $<35 \%$ ) in the transition period (Bernal-Santos et al., 2003; Back and LopezVillalobos, 2004; Castaneda-Gutierrez et al., 2005; Kay et al., 2006a) or in grazing cows (Mackle et al., 2003; Kay et al., 2006b) increases milk yield but does not alter milk production in late-lactation, TMR-fed cows (Chouinard et al., 1999; Perfield et al., 2002). In contrast to moderate MFD, some evidence suggests that severe MFD reduces or limits the ability of CLA to enhance milk synthesis (Chouinard et al., 1999; Mackle et al., 2003; Kay et al., 2006a). This is further illustrated by a marked reduction (40\%) in milk synthesis as a result of abomasally infusing a large amount of a CLA mixture (Bell and Kennelly, 2003), a dose 4-fold greater (based upon the trans-10, cis-12 CLA content) than that necessary to evoke 40\% MFD (Baumgard et al., 2001; de Veth et al., 2004). Despite milk yield changing as we expected (Figure 2), we did not detect the quadratic relationship between milk yield and MFD observed in our earlier transition trial (Kay et al., 2006a). Reasons for this are unclear; nonetheless, a clear relationship exists between moderate MFD and milk yield response in early lactation that does not exist in later lactation and this is probably related to the animals' energetic status (Baumgard et al., 2002b, 2006).

Treatment had no effect on overall DMI, which agrees with previous TMR CLA transition (Bernal-Santos et al., 2003; Moore et al., 2004; Selberg et al., 2004) and pasture-based trials (Mackle et al., 2003; Kay et al., $2006 \mathrm{a}$ ). There was an increase ( $>3 \mathrm{Mcal}$ ) in overall calculated EBAL for both CLA treatments compared with controls (Table 4, Figure 3). This can be directly attributed to MFD because these cows were producing similar or higher volumes of milk and consuming comparable 
Table 6. Effect of supplementing rumen inert-conjugated linoleic acid (RI-CLA) for $40 \mathrm{~d}$ postcalving on milk fatty acid composition in TMR-fed dairy cows ${ }^{1}$

\begin{tabular}{|c|c|c|c|c|c|c|c|}
\hline \multirow[b]{2}{*}{ Fatty acids, mg/g } & \multicolumn{3}{|c|}{ Treatments $^{2}$} & \multirow[b]{2}{*}{ SEM } & \multicolumn{3}{|c|}{$P$} \\
\hline & Control & CLA-1 & CLA-2 & & TRT & TRT $\times$ Day & Contrast $^{3}$ \\
\hline $\mathrm{C} 4: 0$ & $25.68^{\mathrm{a}}$ & $23.65^{\mathrm{b}}$ & $25.29^{\mathrm{ab}}$ & 0.66 & 0.09 & 0.32 & 0.16 \\
\hline C6:0 & $16.49^{\mathrm{a}}$ & $13.57^{\mathrm{b}}$ & $15.90^{\mathrm{ab}}$ & 0.93 & 0.08 & 0.02 & 0.15 \\
\hline C8:0 & $6.32^{\mathrm{a}}$ & $4.97^{\mathrm{b}}$ & $6.17^{\mathrm{ab}}$ & 0.47 & 0.09 & 0.01 & 0.21 \\
\hline C10:0 & 11.28 & 9.39 & 11.65 & 1.03 & 0.25 & 0.02 & 0.57 \\
\hline C12:0 & 12.90 & 11.75 & 13.74 & 1.05 & 0.39 & 0.03 & 0.91 \\
\hline C14:0 & 57.84 & 54.46 & 59.55 & 3.25 & 0.52 & $<0.01$ & 0.84 \\
\hline $\mathrm{C} 14: 1$ cis -9 & 3.18 & 2.90 & 2.61 & 0.25 & 0.30 & 0.03 & 0.19 \\
\hline C15:0 & 4.67 & 4.84 & 5.01 & 0.32 & 0.75 & 0.12 & 0.52 \\
\hline C16:0 & $300.56^{\mathrm{a}}$ & $276.75^{\mathrm{b}}$ & $280.54^{\mathrm{b}}$ & 4.83 & $<0.01$ & 0.01 & $<0.01$ \\
\hline $\mathrm{C} 16: 1$ cis -9 & 15.92 & 15.58 & 14.17 & 1.24 & 0.57 & 0.05 & 0.51 \\
\hline C17:0 & 6.24 & 6.21 & 6.15 & 0.14 & 0.90 & 0.37 & 0.74 \\
\hline C18:0 & 129.60 & 139.94 & 141.78 & 4.94 & 0.20 & 0.99 & 0.08 \\
\hline $\mathrm{C} 18: 1 t-6-8$ & $3.07^{\mathrm{a}}$ & $4.44^{\mathrm{b}}$ & $4.35^{\mathrm{b}}$ & 0.25 & $<0.01$ & $<0.01$ & $<0.01$ \\
\hline C18:1 $t-9$ & $2.49^{\mathrm{a}}$ & $2.56^{\mathrm{b}}$ & $3.40^{\mathrm{b}}$ & 0.20 & $<0.01$ & $<0.01$ & $<0.01$ \\
\hline $\mathrm{C} 18: 1 t-10$ & $4.00^{\mathrm{a}}$ & $8.68^{\mathrm{b}}$ & $9.57^{\mathrm{b}}$ & 1.55 & 0.04 & 0.12 & 0.01 \\
\hline C18:1 $t-11$ & $12.05^{\mathrm{a}}$ & $19.98^{\mathrm{b}}$ & $18.60^{\mathrm{b}}$ & 1.39 & $<0.01$ & $<0.01$ & $<0.01$ \\
\hline $\mathrm{C} 18: 1 t-12$ & $4.47^{\mathrm{a}}$ & $5.93^{\mathrm{b}}$ & $5.71^{\mathrm{b}}$ & 0.40 & 0.04 & 0.05 & 0.01 \\
\hline C18:1 c-9 & 293.27 & 281.90 & 270.22 & 11.94 & 0.41 & 0.01 & 0.26 \\
\hline $\mathrm{C} 18: 2 c-9, c-12$ & $46.82^{\mathrm{a}}$ & $51.89^{\mathrm{b}}$ & $50.11^{\mathrm{ab}}$ & 1.43 & 0.06 & $<0.01$ & 0.03 \\
\hline C20:0 & 0.88 & 0.88 & 0.93 & 0.04 & 0.49 & 0.58 & 0.58 \\
\hline $\mathrm{C} 18: 3 c-9, c-12, c-15$ & 5.11 & 5.29 & 5.22 & 0.24 & 0.86 & 0.74 & 0.62 \\
\hline $\mathrm{C} 18: 2 c-9, t-11$ CLA & $3.50^{\mathrm{a}}$ & $6.60^{\mathrm{b}}$ & $5.72^{\mathrm{b}}$ & 0.36 & $<0.01$ & $<0.01$ & $<0.01$ \\
\hline C18:2 $t-10, c-12$ CLA & $<0.01$ & 1.97 & 1.59 & 0.20 & 0.18 & $<0.01$ & $<0.01$ \\
\hline Other CLA isomers & $0.59^{\mathrm{a}}$ & $9.45^{\mathrm{b}}$ & $7.25^{\mathrm{b}}$ & 1.75 & $<0.01$ & $<0.01$ & $<0.01$ \\
\hline Unknown $^{4}$ & 33.10 & 34.77 & 34.77 & 1.11 & 0.51 & 0.12 & 0.25 \\
\hline Total CLA isomers & $3.83^{\mathrm{a}}$ & $18.02^{\mathrm{b}}$ & $14.55^{\mathrm{c}}$ & 1.30 & $<0.01$ & $<0.01$ & $<0.01$ \\
\hline Total trans isomers & $26.09^{\mathrm{a}}$ & $42.58^{\mathrm{b}}$ & $41.64^{\mathrm{b}}$ & 3.29 & $<0.01$ & $<0.01$ & $<0.01$ \\
\hline \multirow{2}{*}{\multicolumn{8}{|c|}{${ }^{a, b}$ Values within rows with differing superscripts differ at $P<0.05$. }} \\
\hline & & & & & & & \\
\hline \multicolumn{8}{|c|}{$\begin{array}{l}{ }^{2} \text { Treatments were EnerGII (control); } 600 \mathrm{~g} / \mathrm{cow} \text { per d of RI-CLA (CLA-1); stepwise dose of } 600 \mathrm{~g} / \mathrm{cow} \text { per } \\
\text { of RI-CLA followed by } 200 \mathrm{~g} / \mathrm{cow} \text { per d at } 10 \mathrm{DIM} \text { (CLA-2). }\end{array}$} \\
\hline \multicolumn{8}{|c|}{${ }^{3}$ Control vs. CLA-1 and CLA-2. } \\
\hline${ }^{4}$ Represents uniden & ed fattv a & & & & & & \\
\hline
\end{tabular}

quantities of feed throughout the entire trial. The improved calculated EBAL parameters agree with our previous research indicating improved EBAL indices (Moore et al., 2004; Kay et al., 2006a). The improved EBAL status might explain the reduction in BCS loss, because cows in the CLA treatments lost 0.23 compared with 0.53 units of BCS in the controls (Table 4). However, care must be taken in evaluating both BCS and BW changes in a small group of animals because the change in BCS was not corroborated by changes in BW (Table 4). However, as anticipated, the improved calculated EBAL for the CLA treatment groups was substantiated by reductions ( $17 \%$ for CLA- 1 and $22 \%$ for CLA2 ) in circulating NEFA levels (Table 4, Figure 4A), which are thought to closely reflect whole-animal EBAL (Bauman et al., 1988). However, the decrease in NEFA concentration in the current experiment does not agree with other CLA transition trials (Bernal-Santos et al., 2003; Selberg et al., 2004; Castaneda-Gutierrez et al., 2005 ) or even in CLA transition trials when MFD was quickly induced ( $<5$ to 7 DIM) after parturition (Moore et al., 2004; Kay et al., 2006a). The reason for the lack of an effect in the aforementioned trials is unclear, because reducing energy output without altering other components of the EBAL equation should, as we have currently shown (Table 4), decrease the demand to mobilize adipose reserves. Regardless, a reduction in adipose mobilization should benefit a variety of transition cow health issues (fatty liver, ketosis, etc.).

Although supplemental CLA has been shown to improve glucose homeostatic parameters in diabetic models, it paradoxically sometimes causes minor insulin resistance [at doses approximately 10 - to 15 -fold greater (on a $\mathrm{BW}^{0.75}$ basis) than utilized in lactating cow trials] in nondiabetic animal models (Brown and McIntosh, 2003). In the present study, supplemental CLA slightly (11\%) increased circulating glucose levels, possibly indicating a decrease in insulin sensitivity; however, this is in contrast with previous CLA research during established lactation (Baumgard et al., 2000, 2001, 2002c; Perfield et al., 2002) and early lactation (Moore et al., 2004; Castaneda-Gutierrez et al., 2005; 
Kay et al., 2006a). Although small and of questionable biological importance, the apparent decrease in insulin sensitivity may be a partial mechanism by which CLA partitions nutrients from extramammary tissues toward the mammary gland and this may help explain the increase in milk yield in the current trial (Figure 2).

Depending upon DIM, the supplements in the current study provided $29.3 \mathrm{~g}$ (CLA-1) and $9.8 \mathrm{~g}$ (CLA-2) of trans-10, cis-12 CLA/d (an isomer known to cause MFD; Baumgard et al., 2000, 2002c) respectively, and utilizing established equations (de Veth et al., 2004, 2005) we calculated that approximately $10 \mathrm{~g}$ (CLA-1) and 2.8 g (CLA-2) of trans-10, cis-12 CLA escaped biohydrogenation and was available for intestinal absorption. This represents an approximate $6.3 \%$ transfer efficiency rate, which is higher than previous reports utilizing TMR-fed cows in established lactation (Perfield et al., 2002), lower than pasture fed cows in early lactation (Kay et al., 2006a), but similar to those found by Moore et al. (2004) in early lactation. Nonetheless, it appears that a majority of the supplemental CLA is hydrogenated and partially metabolized in the rumen and this is supported by the consistent increase in milk trans 18:1 monoenes (putative products of incomplete CLA hydrogenation) from cows fed CLA (Table 6).

The reason CLA is less effective at reducing milk fat synthesis immediately postpartum (Figure 1) is not clear. As previously stated, the content and transfer efficiency of trans-10, cis-12 CLA was consistent over time (except for the anticipated change at 10 DIM with CLA-2) even though milk fat content and yield gradually decreased as lactation advanced. De novo fatty acids contribute less to the total fatty acid pool in early lactation (compared with established lactation; Bauman and Davis, 1974) and we originally thought that this might be the reason why the mammary gland appears insensitive to CLA immediately postpartum (trans-10, cis-12 CLA is a potent inhibitor of mammary de novo fatty acid synthesis; Baumgard et al., 2000, $2002 a, c)$. However, as we have previously (Kay et al., 2006a) and currently demonstrated, de novo-derived fatty acids actually contribute (on a percentage basis) more to the total fatty acid pool at 2 DIM than they do at 8 DIM (Figure 5), even though CLA had no effect on milk fat content or yield at 2 DIM, but markedly reduced milk fat synthesis at 8 DIM (Figure 1). During established lactation, moderate MFD does not alter the $\Delta^{9}$-desaturase ratios or the overall $\Delta^{9}$-desaturase index, but extensive MFD is often associated with a marked reduction in these desaturase variables (Baumgard et al., 2001). However, similar to our previous transition trials (Moore et al., 2004; Kay et al., 2006a) there were no consistent effects of CLA on the $\Delta^{9}$-desaturase indices (Table 5) and no relationship between these vari-

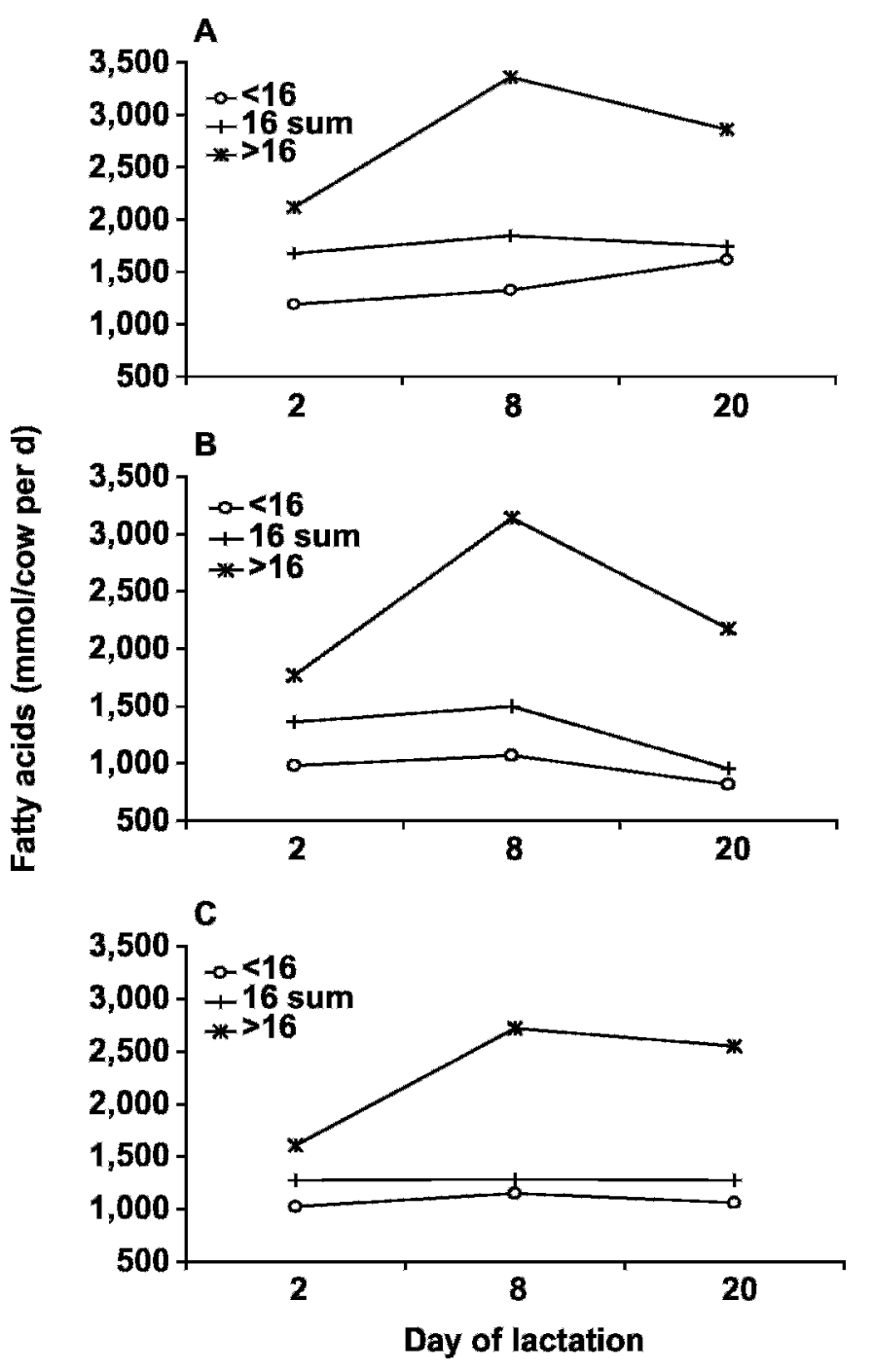

Figure 5. Temporal pattern of fatty acid contribution on a molar basis, divided into origin; de novo (sum of $\mathrm{C} 4: 0$ to $\mathrm{C} 15: 0$ ), de novo and preformed (sum of $\mathrm{C} 16: 0$ and C16:1), and preformed (sum of C17:0 to C20:0) for (A) control, (B) CLA-1, and (C) CLA-2. Treatments were EnerGII (control); 600 g/cow per d of RI-CLA (CLA-1); stepwise dose of $600 \mathrm{~g} / \mathrm{cow}$ per d of RI-CLA followed by $200 \mathrm{~g} / \mathrm{cow}$ per d at 10 DIM (CLA-2).

ables and the temporal pattern or magnitude of CLAinduced MFD (data not shown). The exact reason why CLA is less effective at inducing MFD immediately postpartum remains unknown, but inadequate mammary epithelial cell trans-10, cis-12 CLA uptake, altered milk fatty acid origins (de novo vs. preformed contributions), and an unresponsive $\Delta^{9}$-desaturase system can be ruled out as potential explanations.

\section{CONCLUSIONS}

Dietary CLA can decrease milk fat synthesis in early lactation and this consequently improves calculated 
EBAL and energetic variables (NEFA, glucose); the improved EBAL status allows for increased milk yield. Further research is necessary to determine if CLA-induced improved energetic status is beneficial to animal health and reproduction.

\section{ACKNOWLEDGMENTS}

The authors express their appreciation to Dan Luchini and Bioproducts Inc. (Fairlawn, $\mathrm{OH}$ ) for donating the calcium salts of CLA and EnerGII. The analytical assistance of Sara Sanders and Dennis Hallford (New Mexico State University) was greatly appreciated. The scientific discussions with and cerebral input from Chel Moore and Jane Kay were highly regarded. The technical assistance of Dairy Nutrition Services (Chandler, AZ) and the help of Shannon Baker, Steve and Nancy Faber, Corey Runion, Stephanie Celaya, and the entire crew at the University of Arizona Dairy are greatly appreciated.

\section{REFERENCES}

AOAC. 2000. Official Methods of Analysis. 17th ed. Association of Official Analytical Chemists International, Arlington, VA.

Back, P. J., and N. Lopez-Villalobos. 2004. Effects of a commercial feed containing conjugated linoleic acid on the production of milk components and the value of milk. Proc. N.Z. Soc. Anim. Prod. 64:150-154.

Bauman, D. E., B. A. Corl, L. H. Baumgard, and J. M. Griinari. 2001. Conjugated linoleic acid (CLA) and the dairy cow. Pages 221-250 in Recent Advances in Animal Nutrition. P. C. Garnsworthy and J. Wiseman, ed. Nottingham University Press, Nottingham, UK.

Bauman, D. E., and W. B. Currie. 1980. Partitioning of nutrients during pregnancy and lactation: A review of mechanisms involving homeostasis and homeorhesis. J. Dairy Sci. 63:1514-1529.

Bauman, D. E., and C. L. Davis. 1974. Biosynthesis of Milk Fat. Pages 31-75 in Lactation: A Comprehensive Treatise. Vol. 2. B. L. Larson and V. R. Smith, ed. Academic Press, New York, NY.

Bauman, D. E., C. J. Peel, W. D. Steinhour, P. J. Reynolds, H. F. Tyrrell, C. Brown, and G. L. Harland. 1988. Effect of bovine somatotropin on metabolism of lactating dairy cows: Influence on rates of irreversible loss and oxidation of glucose and nonesterified fatty acids. J. Nutr. 118:1031-1040.

Baumgard, L. H., B. A. Corl, D. A. Dwyer, and D. E. Bauman. 2002c. Effects of conjugated linoleic acid (CLA) on lipid metabolism of lactating dairy cows. J. Anim. Sci. 80:1285-1293.

Baumgard, L. H., B. A. Corl, D. A. Dwyer, A. Sæbo, and D. E. Bauman. 2000. Identification of the conjugated linoleic acid isomer that inhibits milk fat synthesis. Am. J. Physiol. 278:R179-R184.

Baumgard, L. H., E. Matitashvili, B. A. Corl, D. A. Dwyer, and D. E. Bauman. 2002a. Trans-10, cis-12 conjugated linoleic acid decreases lipogenic rates and expression of genes involved in milk lipid synthesis in dairy cows. J. Dairy Sci. 85:2155-2163.

Baumgard, L. H., C. E. Moore, and D. E. Bauman. 2002b. Potential application of conjugated linoleic acids in nutrient partitioning. Pages 127-141 in Proc. Southwest Nutr. Conf., Tucson, Arizona. Online: http://animal.cals.arizona.edu/swnmc/2002/proceedings. php Accessed Oct. 4, 2006.

Baumgard, L. H., L. J. Odens, J. K. Kay, R. P. Rhoads, M. J. VanBaale, and R. J. Collier. 2006. Does negative energy balance (NEBAL) limit milk synthesis in early lactation? Pages 181-187 in Proc. Southwest Nutr. Conf. Online: http://animal.cals.arizona.edu/ swnmc/2006/proceedings.php Accessed Mar. 4, 2006.
Baumgard, L. H., J. K. Sangster, and D. E. Bauman. 2001. Milk fat synthesis in dairy cows is progressively reduced by increasing supplemental amounts of trans-10, cis-12 conjugated linoleic acid (CLA). J. Nutr. 131:1764-1769.

Bell, J. A., and J. J. Kennelly. 2003. Postruminal infusion of conjugated linoleic acids negatively impacts milk synthesis in Holstein cows. J. Dairy Sci. 86:1321-1324.

Bernal-Santos, G., J. W. Perfield, II, D. M. Barbano, D. E. Bauman, and T. R. Overton. 2003. Production responses of dairy cows to dietary supplementation with conjugated linoleic acid (CLA) during the transition period and early lactation. J. Dairy Sci. 86:3218-3228.

Brown, J. M., and M. K. McIntosh. 2003. Conjugated linoleic acid in humans: Regulation of adiposity and insulin sensitivity. J. Nutr. 133:3041-3046.

Butler, W. R. 2001. Nutritional effects on resumption of ovarian cyclicity and conception rate in postpartum dairy cows. In Fertility in the High-Producing Dairy Cow. Br. Soc. Anim. Sci. Occ. Publ. 26:133-145.

Canfield, R. W., and W. R. Butler. 1990. Energy balance and pulsatile luteinizing hormone secretion in early postpartum reproduction and energy balance in dairy cattle. J. Dairy Sci. 73:2342-2349.

Castaneda-Gutierrez, E., T. R. Overton, W. R. Butler, and D. E. Bauman. 2005. Dietary supplements of two doses of calcium salts of conjugated linoleic acid during the transition period and early lactation. J. Dairy Sci. 88:1078-1089.

Chouinard, P. Y., L. Corneau, D. M. Barbano, L. E. Metzger, and D. E. Bauman. 1999. Conjugated linoleic acids alter milk fatty acid composition and inhibit milk fat secretion in dairy cows. J. Nutr. 129:1579-1584.

de Veth, M. J., J. M. Griinari, A. M. Pfeiffer, and D. E. Bauman. 2004. Effect of CLA on milk fat synthesis in dairy cows: Comparison of inhibition by methyl esters and free fatty acids, and relationships among studies. Lipids 39:365-372.

de Veth, M. J., S. K. Gulati, N. D. Luchini, and D. E. Bauman. 2005. Comparison of calcium salts and formaldehyde-protected conjugated linoleic acid in inducing milk fat depression. J. Dairy Sci. 88:1685-1693.

Drackley, J. K. 1999. Biology of dairy cows during the transition period: The final frontier? J. Dairy Sci. 82:2259-2273.

Duff, G. C., D. A. Walker, K. J. Malcolm-Callis, M. W. Wiseman, and D. M. Hallford. 2000. Effects of pre-shipping vs. arrival medication with tilmicosin phosphate and feed chlortetracycline on health and performance of newly received beef cattle. J. Anim. Sci. 78:267-274.

Giesy, J. G., M. A. McGuire, B. Shafii, and T. W. Hanson. 2002. Effect of dose of calcium salts of conjugated linoleic acid (CLA) on percentage and fatty acid content of milk fat in midlactation Holstein cows. J. Dairy Sci. 85:2023-2029.

Hayirli, A., and R. R. Grummer. 2004. Factors affecting dry matter intake prepartum in relationship to etiology of peripartum lipidrelated metabolic disorders: A review. Can. J. Anim. Sci. 84:337-347.

Kay, J. K., T. R. Mackle, D. E. Bauman, N. A. Thomson, and L. H. Baumgard. 2006b. Effects of conjugated linoleic acid on bioenergetic and milk production parameters in grazing dairy cows offered ad libitum or restricted pasture. Proc. N.Z. Soc. Anim. Prod. 66:423-428.

Kay, J. K., J. R. Roche, and L. H. Baumgard. 2006a. Effects of dietary conjugated linoleic acid on production and metabolic parameters in transition dairy cows grazing fresh pasture. J. Dairy Res. 73:367-377.

Lucy, M. C., C. R. Staples, F. M. Michel, and W. W. Thatcher. 1991. Energy balance and size and number of ovarian follicles detected by ultrasonography in early postpartum dairy cows. J. Dairy Sci. $74: 473-482$.

Mackle, T. R., J. K. Kay, M. J. Auldist, A. K. H. McGibbon, B. A. Philpott, L. H. Baumgard, and D. E. Bauman. 2003. Effects of abomasal infusion of conjugated linoleic acid on milk fat concentration and yield form pasture-fed dairy cows. J. Dairy Sci. 86:644-652. 
Moore, C. E., H. C. Hafliger, III, O. B. Mendivil, S. R. Sanders, D. E. Bauman, and L. H. Baumgard. 2004. Increasing amounts of conjugated linoleic acid (CLA) progressively reduces milk fat synthesis immediately postpartum. J. Dairy Sci. 87:1886-1895.

Moore, C. E., J. K. Kay, R. J. Collier, M. J. VanBaale, and L. H. Baumgard. 2005a. Effect of supplemental conjugated linoleic acids on heat-stressed Brown Swiss and Holstein cows. J. Dairy Sci. 88:1732-1740.

Moore, C. E., J. K. Kay, R. P. Rhoads, and L. H. Baumgard. 2005b. A comparison of trans-10, cis-12 CLA effectiveness at inducing milk fat depression (MFD) in early vs. established lactation. J. Dairy Sci. 83(Suppl. 1):210. (Abstr.)

National Research Council. 2001. Nutrient Requirements of Dairy Cattle. 7th rev. ed. Natl. Acad. Press, Washington, DC.
Perfield, J. W., II, G. Bernal-Santos, T. R. Overton, and D. E. Bauman. 2002. Effects of dietary supplementation of rumen-inert conjugated linoleic acid in dairy cows during established lactation. J. Dairy Sci. 85:2609-2617.

Roche, J. R., P. G. Dillon, C. R. Stockdale, L. H. Baumgard, and M. J. VanBaale. 2004. Relationship between international body condition scoring systems. J. Dairy Sci. 87:3076-3079.

SAS Institute. 2005. SAS/STAT Users Guide. Release 9.3. SAS Inst., Inc., Cary, NC.

Selberg, K. T., A. C. Lowe, C. R. Staples, N. D. Luchini, and L. Badinga. 2004. Production and metabolic responses of periparturient Holstein cows to dietary conjugated linoleic acid and transoctadecenoic acids. J. Dairy Sci. 87:158-168.

Tyrrell, H. F., and J. T. Reid. 1965. Prediction of the energy value of cow's milk. J. Dairy Sci. 48:1215-1223. 